\title{
The Cost of Economic Literacy: How Well Does a Literacy-targeted Principles of Economics Course Prepare Students for Intermediate Theory Courses?
}

October 7, 2011

\author{
Donna B. Gilleskie \\ Professor, Department of Economics \\ University of North Carolina at Chapel Hill \\ Department of Economics, CB 3305, Gardner Hall, UNC-CH, Chapel Hill, 27599-3305 \\ Fax: 919-966-4986 \\ Email: donna_gilleskie@unc.edu \\ Michael K. Salemi \\ Professor and Department Chair, Department of Economics \\ University of North Carolina at Chapel Hill \\ Department of Economics, CB 3305, Gardner Hall, UNC-CH, Chapel Hill, 27599-3305 \\ Fax: 919-966-4986 \\ Email: Michael_Salemi@unc.edu
}

\begin{abstract}
Michael K. Salemi is the corresponding author. The paper was prepared for the National Conference on Teaching Economics held at Stanford University on June 1-3, 2011. The authors thank James Self, Indiana University, two anonymous referees, and conference participants for helpful comments. A longer version of the paper with additional description of the literacy targeted principles course and the data used in this study is available at www.unc.edu/ salemi.
\end{abstract}




\begin{abstract}
In a typical economics principles course, students encounter a large number of concepts. In a literacy-targeted course, students study a "short list” of concepts that they can use for the rest of their lives. While a literacy-targeted principles course provides better education for non-majors, it may place economic majors at a disadvantage in post-principles courses. In this paper, we test whether students who completed a literacy targeted principles course earned intermediate theory grades as high as students who completed a traditional principles course. Our findings indicate that students who complete a literacy targeted principles course perform no worse in intermediate theory courses than students who complete a traditional principles course.
\end{abstract}

\title{
Key Words
}

Economic Literacy, Principles of Economics, Intermediate Microeconomic Theory, Intermediate Macroeconomic Theory, Economics Major

Journal of Economic Literature Classification Codes

A22, D00, E00, I21 
Hansen, Salemi and Siegfried (2002, hereafter HSS) argue that the typical college principles course is a missed opportunity to improve economic literacy. HSS point out that 40 percent of college students take a principles course but only two percent major in economics. In the typical course, students encounter a large number of concepts many of which will be useful only to students who take additional courses in economics. In a typical course, students who stop after principles waste course and study time attempting to master tools and language that they will rarely if ever use. In a literacy-targeted (LT) course, students study a "short list" of concepts that they can use for the rest of their lives. They pursue higher-level mastery of fewer topics.

While the LT principles course may provide non-majors with a more valuable educational product, it may place students who choose to major in economics at a disadvantage. LT students who go on to complete intermediate economic theory courses may find that they do not have an adequate foundation on which to build. Alternatively, it is possible that the typical principles course prepares future majors no better than a LT course because student mastery in typical courses is shallow and short lived.

This paper is an attempt to determine whether completing a literacy targeted principles course prepares students for future economics courses as well as the traditional course. The question is important. If the answer is "yes" then it would make sense for the profession to adopt the literacy targeted syllabus as its standard for the economics principles course. If the answer is "no", then there is a tradeoff between best educational practice for economics majors and nonmajors and there is a case for teaching majors and non-majors versions of the principles course.

From 2006 through 2009, Michael Salemi taught a large enrollment, LT principles of economics course at the University of North Carolina-Chapel Hill (UNC-CH). The LT course did not include topics, such as cost curves and macro multipliers, that students taking a single 
economics course would be unlikely to use again. The LT course did include a short list of topics that students could use for the rest of their lives to interpret world events and guide their own decisions. For example, the course devoted 300 minutes of lecture to the concepts of opportunity cost, the benefit-cost principle and comparative advantage and 375 minutes to demand and supply.

The course reallocated the lecture and study time recovered by reducing the number of topics to activities that helped students achieve higher-order mastery of retained material. For example, students kept an economics journal and participated in simulations and discussions.

Our results support the finding that students who complete a LT principles course earn grades as high (and in some cases higher) in intermediate microeconomics and intermediate macroeconomics as students who complete a traditional principles course. While we believe that course grades are an appropriate metric of performance for our study, we agree that other metrics could be used. An advantage of using course grades is that we are able to include in our sample a large number of intermediate economics students taught by many different instructors. One way to restate our chief result is that intermediate theory course instructors were not able to detect any difference between students who completed the LT principles course and students who completed the traditional principles course.

The paper has four sections. The first describes both the literacy targeted and the traditional principles courses taught between 2006 and 2009 at UNC-CH and explains how they were different. The second section describes the data set that we use in the study. It also reports statistics that characterize the principles experience of students in the sample and the grades earned by students. The third section reports the results of equations that we estimate and tests that we conduct to investigate whether or not students who completed a LT principles course 
perform as well in other economics courses as other students. In the final section of the paper, we summarize our findings and draw conclusions.

\section{CONTRASTING THE COURSE CONTENT OF THE LITERACY TARGETED AND TRADITIONAL PRINCIPLES OF ECONOMICS COURSES}

At UNC-CH, Econ 101 (Principles of Economics) is a one semester, three-credit course. The course entails four “contact hours” per week-either three 50-minute or two 75-minute lectures and one 50-minute recitation. The semester allows for fifteen weeks of instruction and either thirteen or fourteen weeks of recitation depending on how holidays fall in the calendar.

The requirements of an Economics major at UNC-CH are standard. Econ 101 is a prerequisite for all courses numbered above the 100 level. In addition to Econ 101, majors must complete Econ 400 (Elementary Statistics), Econ 410 (Intermediate Micro Theory), Econ 420 (Intermediate Macro Theory), and four additional economics courses at the 400-, 500-, or 600-

level with at least one course above the 400-level. Completion of a univariate calculus course is a pre-requisite for Intermediate Microeconomic Theory which in turn is a pre-requisite for most higher-level courses.

In the fall semesters of 2006 through 2009, the LT sections of Econ 101 enrolled approximately 425 students per semester. The text was a custom-published edition of Principles of Economics by Frank and Bernanke that included only assigned chapters. The course calendar provided for two in-class examinations, twenty-seven 75-minute lectures, and fourteen 50minute recitations. The course included a final examination administered according to a university-mandated schedule. 
There are three ways in which the LT course targeted economic literacy. First, the LT course covered fewer topics than traditional principles courses. Second, the course reallocated the resources recovered by omitting some traditional topics to teaching fundamental economic concepts more intensively. Third, the course included assignments that helped students gain a deeper understanding and working knowledge of fundamental concepts and helped them transfer their understanding to contexts and tasks they will encounter throughout their lives. Appendix B describes the LT course in detail and makes the case that the course targeted literacy.

The LT course was different from the courses taken by other students at UNC-CH during the sample period. Most principles students who did not take the LT course between 2006 and 2009 took principles from one of three other instructors, designated A, B, and C in what follows.

Courses taught by A, B, and C required students to read between 24 and 27 chapters from their respective texts while the LT course required them to read only 16 . The chapter discrepancy was greater than the page-number discrepancy because Frank and Bernanke text chapters are longer than chapters in the books used by A, B, and C. They are longer because they contain more examples that guide students in using the concepts to interpret the world around them—an approach that Robert Frank calls “economic naturalism”.

\section{Table 1 about Here}

Courses by A, B, and C covered more topics than the LT course. Table1 presents a list of topics that were not covered in the literacy targeted course but were covered in one of the other courses. The table shows that A, B, and C required students to master many topics that were not included in the LT course and that A, B, and C chose different supplemental topics.

\section{DATA}


The data that we use are part of a master dataset that contains grades earned by every student in every course at UNC-CH between 1995 and 2010. We describe the dataset briefly here and in detail in Appendix A. Of the 74, 610 students in the master dataset, 42.1 percent $(31,431)$ completed at least one economics course at UNC-CH, a rate similar to the 40 percent reported in Siegfried (2000). Of the 31,431, 92.0 percent completed Econ 101 at UNC-CH. The group of 31, 431 students earned 74,610 grades in economics for an average of 2.36 courses per student. Of the 74, 610 students, 6.4 percent declared economics to be their first or second major at some point in their college career. While Margo and Siegfried (1996) report that 2 percent of undergraduates major in economics, Siegfried (2010) reports that the number of undergraduate majors at Ph.D. granting institutions increased substantially between 1996 and 2009.

We use two subsets of the master dataset to study the effects of completing a LT principles course. Dataset A includes students who completed principles of economics at UNCCH during the fall or spring semesters beginning with fall 2006 and ending with fall 2009. Dataset A includes 7,574 students who earned 14,309 course grades in economics for an average of 1.89 grades per student. We exclude the grades of earlier students because no LT course was available to them. We exclude the grades of summer session students because we did not have access to the many different syllabi used in summer school courses and were thus unable to classify those courses as LT or traditional. We use dataset A to test hypotheses about the impact of completing a literacy targeted principles course on performance in later economics courses.

Dataset B is the subset of A that includes students who were observed for at least four semesters after they completed a principles course. Dataset B includes 4,319 students who earned 9,858 economics grades for an average of 2.28 courses per students. We exclude grades earned by other students from dataset B because those students had not exhausted their 
opportunities to take intermediate economics courses. We use dataset B to test hypotheses about the impact of completing a literacy targeted principles course on the propensity to take intermediate economic theory courses.

Table 2 reports course enrollments in the principles course by principles course type. Between fall 2006 and fall 2009, 1597 students completed a literacy-targeted course, 4803 students completed traditional courses taught by A, B, or C, and 1174 students completed other traditional principles courses taught during the regular academic year.

Table 2 about Here

Table 3 reports the distribution of grades earned in the LT and traditional principles courses. In the LT course, students were less likely to earn an A and more likely to earn a B than in traditional sections. The average grade in the LT sections is significantly lower than the average in the traditional sections. The hypothesis that mean grades earned in the literacytargeted and traditional principles courses are equal is rejected by a two-sided t-test at the 10 percent level.

\section{Table 3 about Here}

Table 3 also reports grades earned in intermediate microeconomics, intermediate macroeconomics, and in all other economics courses (conditional on students completing principles at UNC-CH in the fall or spring terms). Students who completed the LT course earned slightly higher grades on average in intermediate microeconomics, intermediate macroeconomics, and in other courses than students who completed the traditional course. We will explore student performance in greater detail later in the paper.

Table 4 reports rates of participation in intermediate microeconomics and intermediate macroeconomics and the propensity to declare a major in economics as a function of the type of 
principles course completed. Overall, 34 percent of the students in Dataset B completed intermediate micro, 29 percent completed intermediate macro, but only 15 percent ever declared economics to be a first or second major. What appears to be an anomaly is explained by the fact that some other major programs such as Business require students to complete intermediate micro but not intermediate macro.

\section{Table 4 about Here}

Table 4 also indicates that students who completed a LT principles course were slightly more likely to enroll in intermediate micro, slightly more likely to enroll in intermediate macro, and slightly less likely to declare an economics major at some point in their careers.

Based on the data reported in Tables 3 and 4, one would conclude that there are no significant differences in later-economic-course performance or in propensity to take later courses between students who completed a LT principles course and students who completed a traditional principles course. However, conclusions at this point are premature because none of the statistical evidence presented so far controls for attributes of students, instructors, or the class setting.

\section{DOES COMPLETION OF A LITERACY TARGED PRINCIPLES COURSE AFFECT FUTURE ECONOMIC EDUCATION OUTCOMES?}

In this section we report our formal analyses of the differential impact of completing a LT principles course. Our analysis has four parts. First, we study how grades in the principles course vary with characteristics of the principles course, the classroom setting and students. Second, we discuss the econometric challenges associated with estimating the impact on later economic education outcomes of completing the LT, rather than the traditional, principles 
course. Third, we report our estimates of the impacts. Fourth, we discuss the robustness of our findings.

\section{Explaining Variation in Principles Course Grades}

We first study variation in grades earned by students in the Principles of Economics course. We do so for two reasons. First, we are interested in understanding whether there are student groups who perform differently in the LT course. Second, we will use principles course grade as an explanatory variable in other equations and thus want to understand how those grades are correlated with student and course characteristics.

Table 5 reports OLS estimates of the equation that we use to explain variation in principles grades observed in Dataset A. We choose norms for the data so that our reference student is a white male resident of North Carolina who took a traditional principles course in a non-honors section. The estimates support several conclusions. First, the estimated coefficients for time and time-squared imply that grade inflation occurred but abated during the period of the study. Second, students in traditional-curriculum honors sections earned an average grade that was 0.46 higher than students in non-honors sections. Third, while the coefficient on the LT indicator variable is insignificantly different from zero, some student groups performed differently than others in the LT course. Females who completed the traditional course earned on average 0.12 grade points less than males who completed the traditional course. Females who took the LT course earned on average 0.25 grade points $(0.124+0.128)$ less than males.

\section{Table 5 about Here}

Fourth, students who completed principles after their freshman year earned lower grades than those who completed principles as first year students. However, these class-cohort effects 
were different in the LT principles course. Juniors earned higher grades in the LT course than in the traditional course while seniors earned even lower grades in the LT course. We conjecture that students who delay completing the principles course until their senior year are less willing to engage the material than younger students and that the lack of engagement has a greater effect on course grade in the LT than in the traditional course.

Fifth, the regression estimates reveal some often-observed demographic effects. African American and Hispanic students earn significantly lower grades than other students. Nonresidents, who as a group have higher aptitude test scores than in-state students, earn higher grades.

Sixth, there are some interesting effects of classroom characteristics on principles grades. There is a significant negative effect of class size on grade. ${ }^{1}$ Students who take the course on a Tuesday-Thursday schedule earn significantly lower grades than students who take the course on a Monday-Wednesday-Friday schedule. And finally, students who take the course in spring semester earn 0.10 less grade points than those who take the course in the fall.

When we re-estimate our principles grade equation with a specification that drops interactions between the LT indicator variable and other variables, the coefficient on the LT principles course indicator is negative but insignificant and other coefficients are very close to their previous values.

\section{Econometric Challenges}

We face four econometric challenges in our attempt to infer from the data whether taking an LT rather than a traditional principles course affects later economic education outcomes. The first challenge is determining whether students who completed the LT and traditional principles courses were different in important ways. The second is determining whether students who 
complete an LT principles course are more or less likely to complete intermediate economic theory courses. The third is providing a remedy for endogeneity bias associated with using principles-course grade in a regression that explains later educational outcomes. The fourth is consideration of the fact that only one instructor taught the LT course. We will discuss each of these challenges in turn.

Were students who enrolled in the LT principles course different? Of course, assignment of students to courses is not random and the instructor of record for most principles courses was known at the time that students enrolled. However, a large majority of students who completed a principles course and went on to complete intermediate economic theory courses took their principles course during their first year. Because the LT course was always offered in the fall semester, first year students who enrolled in it did so during summer orientation before they had much opportunity to learn about instructor reputations from more experienced students. It is true, however, that the syllabus of the LT course was available online for students to consider as they enrolled.

\section{Table 6 about Here}

Table 6 displays group characteristics of students who enrolled in the LT and traditional principles courses and shows that demographically the two groups are very similar. Notably, the fraction of non-NC students is 20 percent for both groups. This is important because, as a group, non-NC residents who enroll at UNC-CH have substantially higher SAT scores. ${ }^{2}$

The second econometric challenge is whether or not students who complete a LT principles course are more likely to complete later courses. To address this second selection problem, we estimated an equation that explains variation in the propensity of students to complete intermediate theory courses. 
Table 7 reports our estimates of logit equations that explain completion of intermediate microeconomics (first column group) and intermediate macroeconomics (third column group) as a function of student and principles-course characteristics. For each explanatory variable, we report the odds ratio and its standard error. The odds ratio is the probability that a student will complete the intermediate course divided by the probability that the student will not complete the course. An odds ratio should be thought of as the marginal effect of the observed characteristic on the probability that a student will complete an intermediate course. We choose norms for the data so that our reference student is a white male resident of North Carolina who earned a C in a non-honors section of a traditional principles course taught by a male instructor.

\section{Table 7 about Here}

There are several interesting results. First, the estimated effect on our reference student of completing the LT rather than the traditional principles course is insignificant--the estimated odds ratio is 0.871 for intermediate micro and 1.09 for intermediate macro and neither is significantly different from 1.0. Second, students with higher grades in the principles course are more likely to complete both intermediate micro and intermediate macro. The odds ratios are 1.9 and 2.2 for intermediate micro and macro and both are significant at the one percent level. Third, the effect of the principles grade on the propensity to take intermediate courses is greater for students who complete the LT principles course than for students who complete the traditional principles course. One possibility is that the selection effect of principles course grade for the decision to complete intermediate micro and macro is stronger for students who complete the LT principles course than for those who complete the traditional principles course. Another possibility is that higher aptitude students who complete the LT principles course are more likely 
to complete intermediate theory courses than high aptitude students who complete a traditional principles course.

There are several demographic effects of interest. Female students are less likely, at the margin, to complete intermediate micro and macro than male students and the type of principles course that female students take seems not to matter. Black, Hispanic and out-of-state students are all more likely to complete intermediate micro than other students. Out-of-state students and Hispanic students are more likely to complete intermediate macro. We do not know why Black students behave differently at the margin than others. One possibility is that Black students are more likely than other demographic groups to complete intermediate microeconomics because it (and not intermediate macroeconomics) is a prerequisite for entry into the undergraduate major program in business.

We repeated the logit estimations with specifications that drop interactions between the LT dummy variable and other variables. The results are presented in the second and fourth column groups of Table 7. Two results stand out. First, the estimated odds ratios associated with completing the LT course are significantly greater than one. Second, all the other odds-ratio estimates are about the same as before.

Overall, the results from Table 7 suggest that students who complete the LT principles course are more likely to complete intermediate micro and macro than students who complete traditional principles courses. For intermediate micro, the effect is accounted for by students who earn higher principles grades. For intermediate macro, the effect is across the board. Later in the paper, we explain what happens when we estimate our participation equation simultaneously with the equation that explains intermediate theory grades. 
The third econometric challenge is the endogenous regressor problem that results from using principles course grades to explain grades in intermediate theory courses. Any attempt to determine whether an educational treatment has an effect on educational outcomes should control for student aptitude. We would prefer to use an exogenous measure of aptitude in our regressions but so far we have been unsuccessful in gaining access to aptitude test score data. The best we can do at this point is to include principles course grades (as well as the dummy variable for out-of-state status) in our regression for intermediate course grades and then check the robustness of our findings by dropping the principles grade from the regressions.

The fourth and final challenge is that only one instructor taught the LT principles course so that we are unable to separate the effect of the LT curriculum from the effect of the instructor who taught it. While we agree that it is important to replicate our findings in other educational settings, we remind the reader that the difference between the LT and traditional courses is that the LT course does not teach many topics taught by the traditional course. One might argue that our LT instructor is an excellent teacher. But, it is hard to understand how our LT instructor's excellence could help students to master topics that the LT instructor did not teach. It is important to note that $\mathrm{A}, \mathrm{B}$, and $\mathrm{C}$ are also excellent instructors each of whom has won at least one teaching award.

\section{The Impact of Completing a LT Principles Course on Performance in Intermediate Theory Courses}

We now turn to the question of greatest interest: Does completion of a LT principles course put students who go on to complete intermediate theory courses at a disadvantage? Table 8 reports our estimates of OLS regressions that explain observed variation in students grades in

intermediate micro (first column group) and macro (third column group). ${ }^{3}$ We choose norms for 
the data so that our reference student is a white male resident of North Carolina who earned a C in a traditional principles course as a first year student and who completed, as a sophomore, a non-honors section of an intermediate theory course taught by a male instructor.

\section{Table 8 about Here}

Other things equal, completing the LT course has little effect on a student's grade in intermediate microeconomics. The only significant effect is embodied in the positive and significant coefficient on the interaction between LT and principles grade which implies that higher-grade students in the LT principles course earn higher intermediate micro grades than higher-grade students in the traditional course (and lower-grade students in the LT principles course earn lower intermediate micro grades than lower-grade students in the traditional course).

The same effect is stronger and more significant in the intermediate macro grade regression. The coefficient on the LT indicator variable is -0.32 while the coefficient on the LTprinciples-grade interaction is 0.19. Both coefficients are significant at the five percent level. These two results and the fact that our norm for the principles grade is a C imply that students who earn less than an A in the LT principles course earn lower grades in intermediate macro than students who earn less than an A in the traditional course. However, when the LT interaction terms are deleted from the macro-grade regression, the coefficient on the LT indicator variable is insignificantly different from zero implying no significant difference between the intermediate macro grades earned by students who completed an LT and traditional principles courses.

The second set of results describes other effects of the principles course on intermediate theory grades. Not surprisingly, students who earn higher grades in their principles course earn higher grades in both intermediate theory courses. On average, a one-point increase in the 
principles grade implies a one-half grade increase in intermediate micro and macro. This finding suggests that students' principles course grades are highly correlated with their ability to do economics. Students who complete their principles course during their first year earn significantly higher grades in both intermediate micro and macro than students who complete principles later in their careers. The longer the principles course is delayed, the stronger is the effect. This finding is consistent with the view that students who take principles in their first year and then go on to complete intermediate theory courses have, other factors unchanged, greater ability than students who complete principles later in their careers and go on to complete intermediate theory courses. Finally, students who earn better than a C in an honors section of principles are predicted to earn a higher grade in intermediate micro (but not intermediate macro) whether they complete the LT or the traditional principles course.

The third set of results describes the effects on intermediate course grades of student, instructor and intermediate-course characteristics. Interestingly, female students earn significantly higher grades than male students in both intermediate micro and intermediate macro while Black students earn lower grades in both courses. The hour at which the intermediate course is offered has no predictive power for course grades but students enrolled in TuesdayThursday intermediate courses earn slightly but significantly higher grades than students enrolled in Monday-Wednesday-Friday intermediate courses. Students taught by teaching assistants earn lower grades in both micro and macro than students taught by regular faculty. Finally, male students taught by female instructors and female students taught by male instructors earn higher intermediate micro grades than other gender combinations.

We estimated alternative specifications that drop interactions between the LT indicator variable and other variables. Two findings stand out. First, for both intermediate micro grades 
(second column group) and intermediate macro grades (fourth column group), there is no significant effect of completing an LT rather than a traditional principles of economics course. Second, all the other coefficient estimates are unaffected by the change in specification.

Overall, the findings reported in Table 8 indicate that students who complete a literacy targeted principles course perform as well in intermediate microeconomics and macroeconomics courses as students who complete a traditional principles course; and students who earn above a C in the literacy targeted principles course perform better than their counterparts who completed a traditional principles course.

Table 9 is similar to Table 8 except that the dependent variable of the estimated equation is grade earned in any post-principles course completed by a student in dataset A. The results are similar to those reported in Table 8 and we highlight the few differences. Table 9 includes the only indication that some students who complete a literacy targeted principles course earn lower grades than other students. The coefficient on the LT indicator variable is -0.24 (0.07); the coefficient on principles grade is 0.375 (0.016); and the coefficient on the LT-grade interaction is 0.07 (0.04). Together, these coefficients imply that the differential effect of completing the LT principles course on post-principles course grade is $-0.24,-0.17$, and -0.09 for students who earned a C, B, and A in the LT principles course. Also, female students who earned a C in the literacy targeted course earned slightly but significantly lower grades than females who earned a $\mathrm{C}$ in the traditional principles course.

\section{Table 9 about Here}

There are a few other differences between Tables 9 and 8 worth noting. First, the effect of principles grade on post-principles course grades (0.38) is smaller than the effect of principles grade on either intermediate micro (0.49) or intermediate macro (0.48). Second, while students 
who complete intermediate theory courses in summer school earn higher grades than students who complete those courses during fall and spring semester, the effect of summer school on grades vanishes when the variable to be explained is grades in all post-principles courses. Third, while student maturity (freshman, sophomore, junior, senior) does not explain grades in intermediate theory courses, it does explain grades in post-principles courses. The estimates indicate that juniors and seniors perform better and first-year students perform worse than sophomores.

Once again, we estimate an alternative specification that drops interactions between the LT indicator variable and other variables. The alternative specification confirms a small but significant negative effect of completing a LT principles course on the average post-principles economics grade. Other coefficient estimates are essentially the same in the two specifications.

\section{Robustness}

Our chief findings are that students who complete the LT principles course are no less likely to complete intermediate theory courses than students who complete a traditional course and, given that they do so, perform as well in those courses as students who complete a traditional principles course. We now check the robustness of these findings.

Our first robustness check is to drop the principles course grade from the intermediate course grade regressions to make sure that our findings are not due to bias that results from using an endogenous regressor. Our results for intermediate micro, intermediate macro, and postprinciples grade average are reported in Table 10.

Table 10 about Here 
Comparison of Table 10 with Tables 8 and 9 confirms that principles course grade has substantial explanatory power for grades in later courses. The adjusted $\mathrm{R}^{2}$ statistics in Table 10 are less than half the values reported in Tables 8 and 9.

For the intermediate micro grade regression, the coefficients on the LT dummy variable and its interactions with other variables are all insignificant. For the intermediate macro grade regression, the coefficient on the LT dummy variable is $-0.263(0.12)$ which is significant at the five percent level. This finding is consistent with that reported in Table 8. However, the reader should keep in mind that the Table 10 regression cannot differentiate between the performance in intermediate macro of LT students who earned a high principles grade and those who earned a low principles grade. For the post-principles average grade regression, Table 10 confirms the small negative effect of completing a LT course rather than a traditional course reported in Table 9.

Comparison of other coefficients in Tables 8 and 9 with their counterparts in Table 10 shows that dropping principles course grades from the three post-principles grade regressions has little effect on the estimated coefficients for student, course and instructor characteristics.

As a second robustness check, we explain intermediate micro, intermediate macro and post-principles grades using a two-stage least squares-procedure to replace a student's observed principles grade with the predicted grade from a first stage regression that uses instructor and course characteristics as instruments. For this procedure we find no difference between performance students who completed traditional and LT principles courses whether the variable to be explained is the grade in intermediate micro, intermediate macro, or any post-principles course. $^{4}$ 
Our third robustness check is to repeat estimation of the equations explaining postprinciples grades on various demographic subsets of data set A. ${ }^{5}$ Our finding that LT principles students perform as well as traditional students in intermediate microeconomics and macroeconomics courses is confirmed for males, females, North Carolina residents, and out-ofstate residents. If we estimate equations separately for principles students who earn an A or a B, then LT students earn slightly (0.144) but significantly higher grades in intermediate micro but the same grades in intermediate macroeconomics. When we repeat estimation of the equation explaining post-principles average economics grade for different demographic groups, we find evidence that the small negative effect of completing a LT principles course seems to be present for female students but not males students and for NC residents but not for out-of state students. When we estimate the post-principles average economics grade equation separately for principles students who earn an A or a B, we find no difference between the performance of students who complete the LT and the traditional principles course. Overall then, our third robustness check confirms our main findings.

Our fourth robustness check is to use Heckman's procedure to estimate simultaneously participation in later courses and grades earned in those courses. The procedure is based on the idea than unobserved characteristics of students may simultaneously explain both their enrollment decisions and their grades. When the residuals of the enrollment and grade equations are correlated, the procedure models that correlation and accounts for it in the course of estimation. Unfortunately, we do not have an instrument for the unobserved characteristic which is necessary for Heckman's procedure to produce efficient estimates. Nevertheless, Heckman's procedure produces estimates that imply that LT principles students earn grades as high in intermediate microeconomics and macroeconomics as traditional principles students. ${ }^{6}$ 


\section{CONLUSIONS}

Our data show that students who completed the LT principles course at the University of North Carolina—Chapel Hill between 2006 and 2009 were at least as likely to enroll in intermediate theory courses as students who completed a traditional principles course. In fact, our estimates imply that students who earned better than a C in the LT principles course were more likely to take intermediate theory courses than students who earned better than a C in the traditional principles course. Our data also show that students who completed the LT principles course performed as well in their intermediate theory courses as students who completed the traditional principles course. However, one of our specifications implies that students who earn a low grade in the LT principles course earn slightly lower intermediate macro grades than students who earn a comparable low grade in the traditional principles course. These findings appear to be robust to variation in equation specification, to variation in data subsets used in estimation, and to our admittedly crude remedies for the endogenous regressor and sample selection problems.

We agree that our attempts to control for selection bias are imperfect. In future work we will attempt to estimate our equations for principles course grade, participation in intermediate theory courses, and intermediate course grades as a simultaneous system which will allow us to model cross-equation residual correlation and to correct our coefficient estimates for selection bias.

We do find one piece of contrasting evidence. When we explain all post-principles grades earned by students in our dataset rather than grades in intermediate theory courses, we find a small negative effect associated with completing the literacy targeted course. We find this result surprising. A priori, we expected any negative effect on future course performance associated 
with completing the LT principles course to be detectable in one or more intermediate theory courses because they, in turn, provide the foundation for field courses in the major. But it may be that the traditional principles course with its broader list of topics has a beneficial effect on student performance in field courses. In any case, we find that students who earn an A in the literacy targeted course perform about as well in all post-principles course as students who earn an A in a traditional principles course.

There is, of course, room for additional work. The most obvious question that we have left unanswered is whether or not completing a literacy-targeted principles course has a detectable and positive impact on economic literacy. We leave that work for the future. At a later date, it may be possible to measure the long-run impact of the literacy targeted and traditional principles courses by assessing the working knowledge of economics of the students in our dataset who completed those courses.

One weakness of our study is its focus on one particular university that offered one particular literacy targeted principles course. We look forward to reading about other studies that check the robustness of our findings to other instructors and other LT syllabi. We believe that such studies are worth doing not only because they are interesting but also because the stakes are high. If our finding proves robust to variation in setting and instructor, then the profession should adopt the literacy targeted principles course as its norm. 


\section{REFERENCES}

Federal Reserve Bank of San Francisco 2004. U.S. Monetary Policy: An Introduction. http://www.frbsf.org/publications/federalreserve/monetary/MonetaryPolicy.pdf.

Frank, R. H. 2005. The Opportunity Cost of Economic Education. New York Times, September 1, 2005.

Frank, R. H. and B. S. Bernanke 2009. Principles of Economics, Fourth Edition. New York: McGraw-Hill Primis.

Hansen, W. L. 2001. Expected Proficiencies for Undergraduate Economics Majors. Journal of Economic Education, 32 (3): 231-42.

Hansen, W. L., M. K. Salemi and J. J. Siegfried 2002. Use It or Lose It: Teaching to Literacy in the Principles of Economics Course. American Economic Review. 92 (2): 463-72.

Kennedy, P. E. 2000. Eight Reasons Why Real versus Nominal Interest Rates Is the Most Important Concept in Macroeconomics Principles Courses. American Economic Review. 90(2): 81-84.

Margo, R. and J. J. Siegfried. 1996. Long-run Trends in Economics Bachelor's Degrees. Journal of Economic Education. 27 (4): 326-36.

Radford, R. A. 1945. The Economic Organization of a P. O. W. Camp. Economica. XII (48): 189-201.

Salemi, M. K. and W. L. Hansen. 2005. Discussing Economics: A Classroom Guide to Preparing Discussion Questions and Leading Discussion. Cheltenham, UK: Edward Elgar.

Siegfried, J.J. 2000. How Many College Students Are Exposed to Economics. Journal of Economic Education. 31(2): 202-04.

Siegfried, J. J. 2010. Trends in Undergraduate Economic Degrees, 1991-2009. Journal of Economic Education. 41(3): 326-30.

Smith, A. 1776, 2000. An Inquiry into the Nature and Causes of the Wealth of Nations. New York: Modern Library Paperback Edition. 
University of North Carolina at Chapel Hill. 2010. Carolina Undergraduate Bulletin, 2010-2011 Record.

Taylor, J. B. 2000. Teaching Modern Macroeconomics at the Principles Level. American Economic Review. 90(2): 90-94. 


\section{TABLES}

Table 1

Coverage of Supplemental Topics in Traditional Principles Courses at UNC-CH

\begin{tabular}{lccc} 
& \multicolumn{3}{c}{ Instructor } \\
Supplemental Topic & A & B & C \\
\hline Budget Constraint Formulas & Yes & No & No \\
Utility Theory & Yes & No & No \\
Indifference Curves & Yes & No & No \\
Average Product & Yes & Yes & Yes \\
Isoquants & Yes & No & No \\
Isocost Lines & Yes & No & No \\
AFC, AVC, ATC & Yes & Yes & Yes \\
Oligopoly & Yes & Yes & Yes \\
Monopolistic Competition & Yes & Yes & Yes \\
Game Theory Models & No & Yes & No \\
of Imperfect Competition & Yes & No & Yes \\
Keynesian Consumption Function & Yes & No & Yes \\
Keynesian Cross & Yes & Yes & Yes \\
Macro Multipliers & Yes & Yes & Yes \\
Money Demand and Supply & Yes & Yes & Yes \\
Bank Expansion Multipliers & Yes & Yes & Yes \\
Aggregate Demand and Supply & & &
\end{tabular}

Table 2

Course Enrollments in Principles of Economics by Principles Course Type

\begin{tabular}{|c|c|c|c|c|c|c|c|c|c|}
\hline \multirow[b]{2}{*}{ Course } & \multirow[b]{2}{*}{ Honors } & \multicolumn{2}{|c|}{ 2006-2007 } & \multicolumn{2}{|c|}{$\begin{array}{l}\text { Academic Yea } \\
2007-2008\end{array}$} & \multicolumn{2}{|c|}{ 2008-2009 } & \multirow{2}{*}{$\begin{array}{c}2009 \\
\text { Fall } \\
\end{array}$} & \multirow[t]{2}{*}{ Total } \\
\hline & & Fall & Spring & Fall & Spring & Fall & Spring & & \\
\hline \multirow[t]{2}{*}{ Literacy Targeted } & No & 397 & & 378 & & 385 & & 394 & 1554 \\
\hline & Yes & & & & & 22 & & 21 & 43 \\
\hline \multirow[t]{2}{*}{ Traditional A } & No & 367 & & & & & & & 367 \\
\hline & Yes & 26 & & & & & & & 26 \\
\hline \multirow[t]{2}{*}{ Traditional B } & No & 90 & 442 & 366 & 371 & & & & 1269 \\
\hline & Yes & & & & & & & & \\
\hline \multirow[t]{2}{*}{ Traditional C } & No & 373 & 350 & 381 & 349 & 806 & 362 & 387 & 3008 \\
\hline & Yes & & 26 & 33 & 35 & & 39 & & 133 \\
\hline Traditional Other & No & & & 95 & 88 & 109 & 439 & 443 & 1174 \\
\hline Total & & 1253 & 818 & 1253 & 843 & 1322 & 840 & 1245 & 7574 \\
\hline
\end{tabular}


Table 3

Grade Distribution in Selected Economics Courses by Principles Course Type

\begin{tabular}{|c|c|c|c|c|c|c|c|c|c|c|}
\hline Course & $\begin{array}{c}\text { Principles } \\
\text { Course Type }\end{array}$ & $\begin{array}{c}\text { Number } \\
\text { of } \\
\text { Grades }\end{array}$ & As & Bs & Cs & Ds & $\mathrm{F}$ & $\mathrm{P} / \mathrm{F}$ & IN/AB & Mean \\
\hline \multirow{2}{*}{ Principles } & Literacy-Targeted & 1597 & 15.27 & 51.35 & 27.43 & 4.01 & 1.19 & 0.04 & 0.04 & 2.76 \\
\hline & Traditional & 5977 & 30.55 & 39.60 & 22.00 & 5.29 & 1.42 & 0.84 & 0.33 & 2.93 \\
\hline Intermediate & Literacy-Targeted & 381 & 43.31 & 39.63 & 12.07 & 3.15 & 0.26 & 0.79 & 0.79 & 3.23 \\
\hline Microeconomics & Traditional & 1506 & 38.18 & 39.18 & 17.60 & 2.99 & 1.39 & 0.40 & 0.26 & 3.09 \\
\hline Intermediate & Literacy-Targeted & 315 & 35.87 & 41.27 & 18.41 & 2.22 & 0.63 & 0.63 & 0.95 & 3.10 \\
\hline Macroeconomics & Traditional & 1161 & 31.01 & 44.62 & 19.47 & 2.76 & 0.77 & 0.95 & 0.43 & 3.03 \\
\hline All Other Econ & Literacy-Targeted & 1192 & 36.49 & 40.86 & 15.02 & 3.52 & 1.43 & 0.84 & 1.85 & 3.09 \\
\hline Courses & Traditional & 5283 & 39.56 & 36.57 & 17.70 & 3.10 & 1.61 & 0.80 & 0.66 & 3.10 \\
\hline
\end{tabular}

Notes:

Dataset A was used to compute these statistics.

“All Other Econ Courses” omits first year seminars because Principles of Economics is not a prerequisite for them.

Table 4

Percent Participation in Selected Economics Courses by Principles Course Type

\begin{tabular}{lcccc}
$\begin{array}{c}\text { Principles } \\
\text { Course Type }\end{array}$ & Number & $\begin{array}{c}\text { Intermediate } \\
\text { Microeconomics }\end{array}$ & $\begin{array}{c}\text { Intermediate } \\
\text { Macroeconomics }\end{array}$ & $\begin{array}{c}\text { Ever Declare } \\
\text { Economics as first } \\
\text { or second major }\end{array}$ \\
\hline $\begin{array}{l}\text { Literacy-Targeted } \\
\text { Traditional }\end{array}$ & 775 & 36.26 & 30.45 & 12.77 \\
Total & 3392 & 33.55 & 28.15 & 16.04 \\
\hline
\end{tabular}

Note: Dataset B was used to compute these statistics. 
Table 5

Estimation Results for Principles Course Grades

\begin{tabular}{|c|c|c|c|c|c|c|}
\hline \multirow{2}{*}{$\begin{array}{l}\text { Dependent Variable } \\
\text { Independent } \\
\text { Variables } \\
\end{array}$} & \multicolumn{6}{|c|}{ Grade in Principles } \\
\hline & COEF & $\mathrm{SE}$ & & COEF & $\mathrm{S}$ & \\
\hline \multicolumn{7}{|l|}{ Principles Characteristics } \\
\hline Literacy Targeted Course & -0.000 & 0.056 & & -0.036 & 0.045 & \\
\hline LT * Honors Section & -0.135 & 0.155 & & & & \\
\hline LT * Female & -0.128 & 0.047 & $* * *$ & & & \\
\hline LT * Non-NC Resident & 0.051 & 0.058 & & & & \\
\hline LT $*$ Took as Sophomore & 0.076 & 0.059 & & & & \\
\hline LT $*$ Took as Junior & 0.193 & 0.092 & ** & & & \\
\hline LT $*$ Took as Senior & -0.244 & 0.153 & & & & \\
\hline LT $*$ Took as Other & 0.102 & 0.405 & & & & \\
\hline Honors Section & 0.462 & 0.080 & $* * *$ & 0.440 & 0.074 & $* * *$ \\
\hline \multicolumn{7}{|l|}{ Student Characteristics } \\
\hline Female & -0.124 & 0.022 & $* * *$ & -0.152 & 0.019 & $* * *$ \\
\hline Black & -0.627 & 0.035 & $* * *$ & -0.631 & 0.035 & $* * *$ \\
\hline Hispanic & -0.306 & 0.043 & $* * *$ & -0.306 & 0.043 & $* * *$ \\
\hline Other Race/Ethnicity & 0.025 & 0.029 & & 0.023 & 0.029 & \\
\hline Non-NC Resident & 0.230 & 0.027 & $* * *$ & 0.238 & 0.024 & $* * *$ \\
\hline \multicolumn{7}{|l|}{ Section Characteristics } \\
\hline Took as Sophomore & -0.145 & 0.027 & $* * *$ & -0.129 & 0.024 & $* * *$ \\
\hline Took as Junior & -0.381 & 0.042 & $* * *$ & -0.343 & 0.037 & $* * *$ \\
\hline Took as Senior & -0.174 & 0.051 & $* * *$ & -0.197 & 0.048 & $* * *$ \\
\hline Took as Other & -0.672 & 0.163 & $* * *$ & -0.653 & 0.149 & $* * *$ \\
\hline Size of Section $($ norm $=300)$ & -0.001 & 0.000 & $* * *$ & -0.001 & 0.000 & $* * *$ \\
\hline Hour of Day (norm=8.0) & -0.009 & 0.008 & & -0.007 & 0.008 & \\
\hline Days of Week: TTH & -0.185 & 0.033 & $* * *$ & -0.186 & 0.033 & $* * *$ \\
\hline \multicolumn{7}{|l|}{ Semester Characteristics } \\
\hline Year $($ norm = 2006) & 0.229 & 0.032 & $* * *$ & 0.226 & 0.032 & $* * *$ \\
\hline Year Squared & -0.066 & 0.011 & $* * *$ & -0.066 & 0.011 & $* * *$ \\
\hline Semester: Spring & -0.101 & 0.023 & $* * *$ & -0.098 & 0.023 & $* * *$ \\
\hline Constant & 3.084 & 0.036 & $* * *$ & 3.087 & 0.035 & $* * *$ \\
\hline Observations & 7,492 & & & 7,492 & & \\
\hline Adjusted R-squared & 0.118 & & & 0.117 & & \\
\hline
\end{tabular}

Dataset A was used to estimate these equations. Norms are chosen for course grades (2.0), class size (300 in principles and 50 in other courses), time of day (8:00 AM), and year $(0=2006, \ldots, 3=2009)$. 
Table 6

Comparison of Group Characteristics of Students Who Completed LT and Traditional Principles Courses

\begin{tabular}{lccc} 
Characteristic & LT & Means & All \\
& Non-LT & 0.513 \\
\hline Female & 0.485 & 0.507 & 0.089 \\
Black & 0.062 & 0.083 & 0.054 \\
Hispanic & 0.060 & 0.055 & 0.133 \\
Other Race/Ethnicity & 0.134 & 0.133 & 0.201 \\
Non-NC Resident & 0.208 & 0.203 & 5907
\end{tabular}

Table 7

Estimation Results for the Propensity to Complete Intermediate Theory Courses

\begin{tabular}{|c|c|c|c|c|c|c|c|c|c|c|c|c|}
\hline \multirow{2}{*}{$\begin{array}{l}\text { Dependent Variable } \\
\text { Independent Variables }\end{array}$} & \multicolumn{7}{|c|}{$\begin{array}{c}\text { Participation } \\
\text { in Micro Economics }\end{array}$} & \multicolumn{5}{|c|}{$\begin{array}{c}\text { Participation } \\
\text { in Macro Economics }\end{array}$} \\
\hline & Odds & \multicolumn{2}{|l|}{ SE } & Odds & \multicolumn{2}{|c|}{$\mathrm{SE}$} & Odds & \multicolumn{2}{|l|}{ SE } & Odds & \multicolumn{2}{|c|}{ SE } \\
\hline Principles Characteristics & & & & & & & & & & & & \\
\hline Literacy Targeted Course & 0.809 & 0.148 & & 1.208 & 0.109 & $* *$ & 1.086 & 0.213 & & 1.246 & 0.120 & $* *$ \\
\hline LT $*$ Grade & 1.517 & 0.216 & $* * *$ & & & & 1.170 & 0.177 & & & & \\
\hline LT $*$ Female & 1.125 & 0.208 & & & & & 1.014 & 0.200 & & & & \\
\hline LT * Non-NC Resident & 0.879 & 0.201 & & & & & 0.917 & 0.218 & & & & \\
\hline Principles Grade & 1.873 & 0.092 & $* * *$ & 1.975 & 0.092 & $* * *$ & 2.226 & 0.125 & $* * *$ & 2.275 & 0.120 & $* * *$ \\
\hline Honors Section & 0.601 & 0.396 & & 0.638 & 0.420 & & 0.236 & 0.204 & $*$ & 0.243 & 0.209 & $*$ \\
\hline Honors Section * Grade & 1.150 & 0.443 & & 1.090 & 0.419 & & 2.011 & 0.971 & & 1.966 & 0.948 & \\
\hline Took as Sophomore & 0.537 & 0.049 & $* * *$ & 0.535 & 0.049 & $* * *$ & 0.388 & 0.040 & $* * *$ & 0.388 & 0.040 & $* * *$ \\
\hline Took as Junior & 0.322 & 0.052 & $* * *$ & 0.324 & 0.053 & $* * *$ & 0.231 & 0.045 & $* * *$ & 0.231 & 0.045 & $* * *$ \\
\hline Took as Senior & 0.061 & 0.024 & $* * *$ & 0.060 & 0.024 & $* * *$ & 0.062 & 0.026 & $* * *$ & 0.061 & 0.026 & $* * *$ \\
\hline Took as Other & 0.648 & 0.360 & & 0.664 & 0.336 & & 0.621 & 0.376 & & 0.629 & 0.380 & \\
\hline Student Characteristics & & & & & & & & & & & & \\
\hline Female & 0.454 & 0.036 & $* * *$ & 0.459 & 0.033 & $* * *$ & 0.423 & 0.036 & $* * *$ & 0.422 & 0.032 & $* * *$ \\
\hline Black & 1.707 & 0.229 & $* * *$ & 1.703 & 0.228 & $* * *$ & 1.175 & 0.178 & & 1.177 & 0.178 & \\
\hline Hispanic & 1.358 & 0.211 & $* *$ & 1.338 & 0.208 & $*$ & 1.417 & 0.231 & $* *$ & 1.412 & 0.230 & $* *$ \\
\hline Other Race/Ethnicity & 1.256 & 0.138 & $* *$ & 1.237 & 0.136 & $*$ & 0.976 & 0.115 & & 0.971 & 0.114 & \\
\hline Non-NC Resident & 1.294 & 0.126 & $* * *$ & 1.283 & 0.113 & $* * *$ & 1.407 & 0.144 & $* * *$ & 1.392 & 0.129 & $* * *$ \\
\hline Constant & 0.462 & 0.038 & $* * *$ & 0.437 & 0.035 & $* * *$ & 0.326 & 0.030 & $* * *$ & 0.319 & 0.028 & $* * *$ \\
\hline Observations & 4,167 & & & 4,167 & & & 4,167 & & & 4,167 & & \\
\hline Pseudo R-squared & 0.124 & & & 0.122 & & & 0.155 & & & 0.155 & & \\
\hline
\end{tabular}

Dataset B was used to estimate these equations. Norms are chosen for course grades (2.0), class size (300 in principles and 50 in other courses), time of day (8:00 AM), and year $(0=2006, . ., 3=2009)$. 
Table 8

\section{Estimation Results for Intermediate Theory Grades}

Dependent Variable
Intermediate Micro Grade
Intermediate Macro Grade

\begin{tabular}{|c|c|c|c|c|c|c|c|c|c|c|c|c|}
\hline Independent Variable & COEF & SE & & COEF & SE & & COEF & SE & & COEF & SE & \\
\hline \multicolumn{13}{|l|}{ Principles Characteristics } \\
\hline Literacy Targeted Course & -0.086 & 0.127 & & 0.071 & 0.084 & & -0.316 & 0.138 & $* *$ & -0.110 & 0.095 & \\
\hline LT * Grade & 0.136 & 0.072 & $*$ & & & & 0.189 & 0.077 & $* *$ & & & \\
\hline LT $*$ Honors Section & 0.004 & 0.332 & & & & & -0.068 & 0.365 & & & & \\
\hline LT * Female & -0.041 & 0.090 & & & & & 0.052 & 0.098 & & & & \\
\hline LT * Non-NC Resident & 0.052 & 0.098 & & & & & -0.104 & 0.101 & & & & \\
\hline Principles Grade & 0.493 & 0.028 & $* * *$ & 0.511 & 0.026 & $* * *$ & 0.479 & 0.031 & $* * *$ & 0.509 & 0.029 & $* * *$ \\
\hline Honors Section & -0.534 & 0.386 & & -0.509 & 0.382 & & 0.170 & 0.538 & & 0.188 & 0.535 & \\
\hline Honors Section * Grade & 0.425 & 0.211 & $* *$ & 0.414 & 0.211 & $* *$ & 0.092 & 0.291 & & 0.080 & 0.291 & \\
\hline Took as Sophomore & -0.136 & 0.058 & $* *$ & -0.135 & 0.058 & ** & -0.199 & 0.065 & $* * *$ & -0.195 & 0.065 & $* * *$ \\
\hline Took as Junior & -0.356 & 0.113 & $* * *$ & -0.352 & 0.113 & $* * *$ & -0.372 & 0.140 & $* * *$ & -0.358 & 0.140 & $* *$ \\
\hline Took as Senior & -0.638 & 0.264 & $* *$ & -0.641 & 0.264 & $* *$ & -0.698 & 0.326 & $* *$ & -0.689 & 0.326 & $* *$ \\
\hline Took as Other & -0.444 & 0.417 & & -0.421 & 0.417 & & -0.430 & 0.392 & & -0.407 & 0.392 & \\
\hline \multicolumn{13}{|l|}{ Student Characteristics } \\
\hline Female & 0.177 & 0.045 & $* * *$ & 0.165 & 0.039 & $* * *$ & 0.148 & 0.050 & $* * *$ & 0.160 & 0.043 & $* * *$ \\
\hline Black & -0.158 & 0.064 & $* *$ & -0.159 & 0.064 & $* *$ & -0.150 & 0.074 & $* *$ & -0.140 & 0.074 & * \\
\hline Hispanic & -0.178 & 0.075 & ** & -0.183 & 0.075 & ** & 0.010 & 0.076 & & 0.007 & 0.06 & \\
\hline Other Race/Ethnicity & -0.037 & 0.049 & & -0.043 & 0.049 & & 0.019 & 0.053 & & 0.013 & 0.053 & \\
\hline Non-NC Resident & 0.093 & 0.045 & $* *$ & 0.106 & 0.040 & $* * *$ & 0.052 & 0.047 & & 0.032 & 0.042 & \\
\hline Took as Freshman & -0.076 & 0.054 & & -0.072 & 0.054 & & -0.354 & 0.070 & $* * *$ & -0.354 & 0.070 & $* * *$ \\
\hline Took as Junior & -0.111 & 0.058 & $*$ & -0.109 & 0.058 & $*$ & -0.014 & 0.060 & & -0.011 & 0.060 & \\
\hline Took as Senior & -0.148 & 0.104 & & -0.152 & 0.104 & & 0.015 & 0.108 & & 0.009 & 0.108 & \\
\hline Took as Other & -0.901 & 0.658 & & -0.906 & 0.658 & & -1.027 & 0.783 & & -1.078 & 0.783 & \\
\hline \multicolumn{13}{|l|}{ Section Characteristics } \\
\hline Honors Section & -0.056 & 0.164 & & -0.057 & 0.163 & & 0.188 & 0.135 & & 0.181 & 0.135 & \\
\hline Size & 0.003 & 0.001 & $* * *$ & 0.003 & 0.001 & $* * *$ & 0.003 & 0.000 & $* * *$ & 0.003 & 0.000 & $* * *$ \\
\hline Hour of Day & 0.015 & 0.017 & & 0.012 & 0.015 & & 0.027 & 0.019 & & 0.025 & 0.017 & \\
\hline Days of Week: TTH & 0.131 & 0.050 & $* * *$ & 0.135 & 0.050 & $* * *$ & 0.237 & 0.054 & $* * *$ & 0.242 & 0.054 & $* * *$ \\
\hline \multicolumn{13}{|l|}{ Instructor Characteristics } \\
\hline Female & 0.148 & 0.060 & $* *$ & 0.146 & 0.058 & $* *$ & 0.113 & 0.063 & * & 0.118 & 0.061 & * \\
\hline Female * Female Student & -0.160 & 0.085 & $*$ & -0.146 & 0.082 & * & -0.072 & 0.092 & & -0.083 & 0.088 & \\
\hline Teaching Assistant & -0.187 & 0.092 & $* *$ & -0.194 & 0.092 & ** & -0.256 & 0.099 & $* * *$ & -0.264 & 0.099 & $* * *$ \\
\hline \multicolumn{13}{|l|}{ Semester Characteristics } \\
\hline Year & -0.374 & 0.066 & $* * *$ & -0.368 & 0.066 & $* * *$ & -0.202 & 0.088 & $* *$ & -0.196 & 0.088 & ** \\
\hline Year Squared & 0.095 & 0.019 & $* * *$ & 0.093 & 0.019 & $* * *$ & 0.036 & 0.024 & & 0.033 & 0.024 & \\
\hline Semester: Spring & 0.009 & 0.042 & & 0.012 & 0.042 & & -0.064 & 0.045 & & -0.062 & 0.045 & \\
\hline Semester: Summer School & 0.256 & 0.066 & $* * *$ & 0.253 & 0.066 & $* * *$ & 0.391 & 0.074 & $* * *$ & 0.387 & 0.074 & $* * *$ \\
\hline Constant & 2.675 & 0.084 & $* * *$ & 2.653 & 0.082 & $* * *$ & 2.449 & 0.104 & $* * *$ & 2.411 & 0.102 & $* * *$ \\
\hline Obser & 1,871 & & & 1,871 & & & 1,455 & & & 1455 & & \\
\hline Adjusted R-squared & 0.266 & & & 0.266 & & & 0.277 & & & 0.275 & & \\
\hline
\end{tabular}

Dataset A was used to estimate these equations. Norms are chosen for course grades (2.0), class size (300 in principles and 50 in other courses), hour of day (8:00 AM), and year $(0=2006, . ., 3=2009)$. 
Table 9

Estimation Results for

All Post-Principles Economics Grades

Dependent Variable Average Post-Principles Grade

\begin{tabular}{|c|c|c|c|c|c|c|}
\hline Independent Variable & COEF & $\mathrm{SE}$ & & COEF & & SE \\
\hline \multicolumn{7}{|l|}{ Principles Characteristics } \\
\hline Literacy Targeted Course & -0.241 & 0.069 & $* * *$ & -0.196 & 0.047 & $* * *$ \\
\hline LT * Grade & 0.072 & 0.042 & $*$ & & & \\
\hline LT * Honors Section & 0.091 & 0.218 & & & & \\
\hline LT * Female & -0.139 & 0.055 & $* *$ & & & \\
\hline LT * Non-NC Resident & 0.028 & 0.061 & & & & \\
\hline Principles Grade & 0.375 & 0.016 & $* * *$ & 0.383 & 0.015 & $* * *$ \\
\hline Honors Section & -0.251 & 0.261 & & -0.237 & 0.260 & \\
\hline Honors Section * Grade & 0.298 & 0.142 & $* *$ & 0.293 & 0.142 & $* *$ \\
\hline Took as Sophomore & -0.299 & 0.030 & $* * *$ & -0.298 & 0.030 & $* * *$ \\
\hline Took as Junior & -0.553 & 0.054 & $* * *$ & -0.553 & 0.053 & $* * *$ \\
\hline Took as Senior & -0.826 & 0.135 & $* * *$ & -0.825 & 0.135 & $* * *$ \\
\hline Took as Other & -0.427 & 0.294 & & -0.412 & 0.294 & \\
\hline \multicolumn{7}{|l|}{ Student Characteristics } \\
\hline Female & 0.333 & 0.023 & $* * *$ & 0.311 & 0.021 & $* * *$ \\
\hline Black & -0.347 & 0.039 & $* * *$ & -0.349 & 0.039 & $* * *$ \\
\hline Hispanic & -0.244 & 0.043 & $* * *$ & -0.244 & 0.044 & $* * *$ \\
\hline Other Race/Ethnicity & -0.049 & 0.029 & $*$ & -0.050 & 0.029 & * \\
\hline Non-NC Resident & 0.040 & 0.027 & & 0.045 & 0.024 & * \\
\hline Took as Freshman & -0.187 & 0.041 & $* * *$ & -0.185 & 0.041 & $* * *$ \\
\hline Took as Junior & 0.164 & 0.028 & $* * *$ & 0.165 & 0.028 & $* * *$ \\
\hline Took as Senior & 0.110 & 0.039 & $* * *$ & 0.105 & 0.039 & $* * *$ \\
\hline Took as Other & -0.423 & 0.392 & & -0.421 & 0.392 & \\
\hline \multicolumn{7}{|l|}{ Section Characteristics } \\
\hline Honors Section & -0.064 & 0.105 & & -0.064 & 0.105 & \\
\hline Size & -0.001 & 0.000 & $* * *$ & -0.001 & 0.000 & $* * *$ \\
\hline Hour of Day & 0.010 & 0.009 & & 0.008 & 0.009 & \\
\hline Days of Week: TTH & 0.285 & 0.027 & $* * *$ & 0.291 & 0.027 & $* * *$ \\
\hline \multicolumn{7}{|l|}{ Instructor Characteristics } \\
\hline Teaching Assistant & -0.001 & 0.022 & & -0.005 & 0.022 & \\
\hline \multicolumn{7}{|l|}{ Semester Characteristics } \\
\hline Year & -0.165 & 0.044 & $* * *$ & -0.157 & 0.044 & $* * *$ \\
\hline Year Squared & 0.030 & 0.012 & $* *$ & 0.029 & 0.012 & $* *$ \\
\hline Semester: Spring & -0.146 & 0.023 & $* * *$ & -0.145 & 0.023 & $* * *$ \\
\hline Semester: Summer School & 0.041 & 0.041 & & 0.042 & 0.041 & \\
\hline Constant & 2.721 & 0.055 & $* * *$ & 2.716 & 0.055 & $* * *$ \\
\hline Observations & 6,366 & & & 6,366 & & \\
\hline Adjusted R-squared & 0.208 & & & 0.207 & & \\
\hline
\end{tabular}

Dataset A was used to estimate these equations. Norms are chosen for course grades (2.0), class size (300 in principles and 50 in other courses), time of day (8:00 AM), and year $(0=2006, . ., 3=2009)$. 


\section{Table 10}

Robustness Check: Dropping Principles Grade from Intermediate Grade Regressions

\begin{tabular}{|c|c|c|c|c|c|c|c|c|c|}
\hline \multirow{2}{*}{$\begin{array}{l}\text { Dependent Variable } \\
\text { Independent Variable }\end{array}$} & \multicolumn{3}{|c|}{$\begin{array}{l}\text { Intermediate } \\
\text { Micro Grade }\end{array}$} & \multicolumn{3}{|c|}{$\begin{array}{l}\text { Intermediate } \\
\text { Macro Grade }\end{array}$} & \multicolumn{3}{|c|}{$\begin{array}{l}\text { Post-Principles } \\
\text { Average Grade }\end{array}$} \\
\hline & COEF & SE & & COEF & SE & & COEF & SE & \\
\hline \multicolumn{10}{|l|}{ Principles Characteristics } \\
\hline Literacy Targeted Course & -0.057 & 0.110 & & -0.263 & 0.121 & $* *$ & -0.227 & 0.057 & $* * *$ \\
\hline LT $*$ Honors Section & 0.297 & 0.363 & & 0.308 & 0.400 & & 0.218 & 0.227 & \\
\hline LT * Female & -0.070 & 0.099 & & 0.047 & 0.108 & & -0.086 & 0.058 & \\
\hline LT * Non-NC Resident & 0.037 & 0.107 & & -0.108 & 0.111 & & 0.014 & 0.064 & \\
\hline Honors Section & 0.343 & 0.130 & $* * *$ & 0.478 & 0.138 & $* * *$ & 0.452 & 0.061 & $* * *$ \\
\hline Took as Sophomore & -0.090 & 0.064 & & -0.157 & 0.072 & $* *$ & -0.250 & 0.032 & $* * *$ \\
\hline Took as Junior & -0.271 & 0.125 & $* *$ & -0.383 & 0.155 & $* *$ & -0.570 & 0.056 & $* * *$ \\
\hline Took as Senior & -0.772 & 0.291 & $* * *$ & -0.479 & 0.360 & & -0.848 & 0.142 & $* * *$ \\
\hline Took as Other & -0.401 & 0.459 & & -0.215 & 0.434 & & -0.297 & 0.309 & \\
\hline \multicolumn{10}{|l|}{ Student Characteristics } \\
\hline Female & 0.164 & 0.050 & $* * *$ & 0.120 & 0.056 & $* *$ & 0.274 & 0.024 & $* * *$ \\
\hline Black & -0.412 & 0.069 & $* * *$ & -0.390 & 0.080 & $* * *$ & -0.527 & 0.041 & $* * *$ \\
\hline Hispanic & -0.312 & 0.082 & $* * *$ & -0.143 & 0.084 & * & -0.360 & 0.046 & $* * *$ \\
\hline Other Race/Ethnicity & -0.019 & 0.054 & & 0.052 & 0.059 & & -0.004 & 0.030 & \\
\hline Non-NC Resident & 0.159 & 0.049 & $* * *$ & 0.125 & 0.052 & $* *$ & 0.121 & 0.028 & $* * *$ \\
\hline Took as Freshman & 0.069 & 0.059 & & -0.342 & 0.078 & $* * *$ & -0.104 & 0.043 & $* *$ \\
\hline Took as Junior & -0.280 & 0.064 & $* * *$ & -0.107 & 0.066 & & 0.022 & 0.029 & \\
\hline Took as Senior & -0.436 & 0.114 & $* * *$ & -0.213 & 0.118 & * & -0.004 & 0.041 & \\
\hline Took as Other & -1.623 & 0.724 & $* *$ & -0.945 & 0.866 & & -0.956 & 0.412 & $* *$ \\
\hline \multicolumn{10}{|l|}{ Section Characteristics } \\
\hline Honors Section & 0.072 & 0.181 & & 0.294 & 0.148 & $* *$ & 0.023 & 0.111 & \\
\hline Size & 0.002 & 0.001 & $*$ & 0.003 & 0.001 & $* * *$ & -0.001 & 0.000 & $* * *$ \\
\hline Time of Day & 0.035 & 0.019 & $*$ & 0.050 & 0.021 & $* *$ & 0.026 & 0.010 & $* * *$ \\
\hline Days of Week: TTH & 0.064 & 0.055 & & 0.152 & 0.060 & $* *$ & 0.187 & 0.028 & $* * *$ \\
\hline \multicolumn{10}{|l|}{ Instructor Characteristics } \\
\hline Female & 0.114 & 0.066 & * & 0.098 & 0.070 & & + & & \\
\hline Female * Female Student & -0.152 & 0.093 & & -0.065 & 0.102 & & + & & \\
\hline Teaching Assistant & -0.078 & 0.101 & & -0.154 & 0.109 & & -0.019 & 0.024 & \\
\hline \multicolumn{10}{|l|}{ Semester Characteristics } \\
\hline Year & -0.278 & 0.072 & $* * *$ & -0.138 & 0.097 & & -0.141 & 0.046 & $* * *$ \\
\hline Year Squared & 0.081 & 0.021 & $* * *$ & 0.027 & 0.027 & & 0.035 & 0.013 & $* * *$ \\
\hline Semester: Spring & 0.004 & 0.047 & & -0.097 & 0.049 & $*$ & -0.130 & 0.024 & $* * *$ \\
\hline Semester: Summer School & 0.209 & 0.073 & $* * *$ & 0.409 & 0.082 & $* * *$ & 0.058 & 0.043 & \\
\hline Constant & 3.186 & 0.087 & $* * *$ & 3.020 & 0.106 & $* * *$ & 3.156 & 0.055 & $* * *$ \\
\hline Observations & 1,871 & & & 1,455 & & & 6,366 & & \\
\hline Adjusted R-squared & 0.121 & & & 0.132 & & & 0.126 & & \\
\hline
\end{tabular}

Dataset A was used to estimate these equations. Norms are chosen for course grades (2.0), class size (300 in principles and 50 in other courses), time of day (8:00), and year $(0=2006, . ., 3=2009)$.

+ The registrar records did not always correctly identify the primary instructor in courses where teaching assistants were employed so that we were unable to determine the gender of instructors for some economics courses in the sample. 


\section{APPENDIX A: THE DATA}

The master dataset from which we take the data used in our project comprises every grade earned by every student in every course at the University of North Carolina at Chapel Hill beginning in fall semester1995 and ending in fall semester 2009. The master dataset includes 2.05 million grades earned by 74,610 students.

Table A1 shows how students whose grades are included in the master dataset vary by the academic term in which their first grade was observed. For the initial academic year, 1995-96, the master dataset includes only first year students and thus does not include transfer students.

Table A1

Classification of Students in the Master Dataset

By Date of First Recorded Grade

(Number of Students)

\begin{tabular}{crrrrr} 
Academic Year & \multicolumn{5}{c}{ Academic Term } \\
& \multicolumn{1}{c}{ Fall } & Spring & 1st SS & 2nd SS & Total \\
\hline $1995-1996$ & 3268 & 25 & 13 & 80 & 3386 \\
$1996-1997$ & 4022 & 160 & 448 & 417 & 5047 \\
$1997-1998$ & 4115 & 190 & 457 & 352 & 5114 \\
$1998-1999$ & 4071 & 200 & 364 & 381 & 5016 \\
$1999-2000$ & 4078 & 179 & 375 & 328 & 4960 \\
$2000-2001$ & 4077 & 156 & 374 & 352 & 4959 \\
$2001-2002$ & 4296 & 182 & 438 & 373 & 5289 \\
$2002-2003$ & 4011 & 157 & 451 & 316 & 4935 \\
$2003-2004$ & 4177 & 175 & 386 & 318 & 5056 \\
$2004-2005$ & 4288 & 162 & 400 & 331 & 5181 \\
$2005-2006$ & 4449 & 138 & 415 & 292 & 5294 \\
$2006-2007$ & 4484 & 224 & 224 & 254 & 5186 \\
$2007-2008$ & 4586 & 234 & 203 & 275 & 5298 \\
$2008-2009$ & 4571 & 220 & 182 & 295 & 5268 \\
$2009-2010$ & 4621 & 0 & 0 & 0 & 4621 \\
Total & 63114 & 2402 & 4730 & 4364 & 74610
\end{tabular}

Of the 74, 610 students in the master dataset, 31,431 (42.1\%) took at least one economics course at UNC$\mathrm{CH}$. Of those 31,431 students, 28,914 (92.0\%) took principles of economics at UNC-CH. The group of 31, 431 students who took at least one economics course earned 74,210 grades in economics for an average of 2.36 courses per student.

Table A2 reports rates of participation in economics courses by students in the master dataset. Several of the reported results are noteworthy. Of the 74,610 students for whom we observe entire histories of their coursework while at UNC-CH, 38.8 percent complete principles of economics. ${ }^{1}$ About 6.4 percent of

\footnotetext{
${ }^{1}$ Note that we only observe right-censored histories of coursework for students matriculating in the later years of our observed time frame. Similarly, coursework is right-censored for students who take a leave of absence from the university before graduating.
} 
students list economics as a first or second major at some point during their college career. ${ }^{2}$ Among those who complete principles of economics, only 12.2 percent list economics as their major which underscores the point made by Hansen, Salemi and Siegfried (2002) that a traditional principles course targets the educational objectives of a small fraction of students who complete the course. . $^{3}$

\section{Table A2 \\ Participation Rates in Economics Courses}

\begin{tabular}{lcc} 
Type of Participation & $\begin{array}{c}\text { Sample Size }^{\text {a }} \\
\end{array}$ & $\begin{array}{c}\text { Participation } \\
\text { (Percent) }\end{array}$ \\
\hline Complete Principles of Economics & 74,610 & 38.75 \\
Complete Intermediate Microeconomics & 74,610 & 15.33 \\
$\quad$ Conditional on Completing Principles at UNC-CH ${ }^{\text {b }}$ & 28,914 & 33.50 \\
Complete Intermediate Macroeconomics & 74,610 & 11.32 \\
$\quad$ Conditional on Completing Principles at UNC-CH & 28,914 & 24.28 \\
$\quad$ Conditional on Completing Principles and Intermediate Microeconomics at UNC-CH & 9,686 & 68.35 \\
& & 6.35 \\
Declare Economics to be First or Second Major c & 74,610 & 12.17 \\
$\quad$ Conditional on Completing Principles at UNC-CH & 28,914 & 32.22 \\
$\quad$ Conditional on Completing Principles and Intermediate Micro at UNC-CH & 9,686 & 6,620 \\
$\quad$ Conditional on Principles, Micro, and Macro at UNC-CH & & 43.41
\end{tabular}

Notes:

a. Sample size denotes the number of students in the denominator of the participation ratio reported in the second column.

b. 1753 students take Intermediate Micro and 1426 take Intermediate Macro without completing Principles at UNC-CH.

c. The declaration occurred at some point in the student's career. We do not have access to final student grade transcripts. Also, student careers at UNC are potentially right censored.

Table A3 reports average grades earned by students completing a principles of economics course at UNC-CH between fall semester 1995 and fall semester 2009. Grade inflation occurred over the fifteen years of the sample. While the average principles grade over the sample was 2.67, the average grade was 2.51 in 1995-96 and 2.96 in 2008-2009. ${ }^{4}$

\footnotetext{
${ }^{2}$ This figure is not based on reported major(s) at graduation but on whether the individual listed economics as his first or second major during any semester while at UNC-CH.

${ }^{3}$ Among those who took principles and intermediate micro, 32.21 percent list economics as a major. Among those who take principles, intermediate micro and intermediate macro, 43.39 percent list it as their major. These numbers may be slightly underreported because we do not observe the entire history of coursework for students who entered near the end of the time frame in which the data are available.

${ }^{4}$ Note that of the 28,914 students who took Principles at UNC during our time frame, only 28,734 of the grades assigned were numeric. That is, students could have taken the course Pass/Fail, or they could have received an incomplete or they were absent for the final exam. We calculate average grades using grades assigned 4.0 (A), 3.7 (A-), $3.3(\mathrm{~B}+)$ through $0.7(\mathrm{D}-)$, and $0.0(\mathrm{~F})$. Incompletes or absences may be made up, but at the time the data were retrieved, this grade was recorded on the system. There are no attempts to go back in time to change "corrected" grades. In addition, there are some students who took Principles multiple times. We include in the following averages by semester the numeric grades of all students taking Principles regardless of how many times they have taken it in the past. Hence, in Table 7 we use 29,717 grades to construct average Principles grades each semester from fall 1995 to fall 2009. Of the 28,914 students over this time period, 1 student took Principles five times, 7 students took it four times, 52 took it three times, and 872 took it twice.
} 
Table A3

Average Grade in Principles of Economics at UNC-CH

(on a 4.0 scale)

\begin{tabular}{|c|c|c|c|c|c|c|c|c|c|c|}
\hline \multirow[b]{2}{*}{ Academic Year } & \multicolumn{5}{|c|}{ Average Grade } & \multicolumn{5}{|c|}{ Number of Numeric Grades } \\
\hline & Fall & Spring & 1st SS & 2nd SS & Total & Fall & Spring & 1st SS & 2nd SS & Total \\
\hline 1995-1996 & 2.56 & 2.46 & 2.44 & 2.50 & 2.51 & 446 & 467 & 27 & 10 & 950 \\
\hline 1996-1997 & 2.68 & 2.49 & 2.74 & 2.21 & 2.58 & 793 & 802 & 65 & 51 & 1711 \\
\hline 1997-1998 & 2.53 & 2.46 & 2.54 & - & 2.50 & 972 & 749 & 109 & 0 & 1830 \\
\hline 1998-1999 & 2.50 & 2.33 & 2.83 & 2.65 & 2.46 & 1021 & 807 & 122 & 87 & 2037 \\
\hline $1999-2000$ & 2.50 & 2.51 & 2.79 & 2.66 & 2.53 & 1034 & 907 & 126 & 78 & 2145 \\
\hline 2000-2001 & 2.51 & 2.45 & 2.60 & 2.59 & 2.50 & 1098 & 806 & 151 & 78 & 2133 \\
\hline 2001-2002 & 2.48 & 2.60 & 2.68 & 2.29 & 2.53 & 1162 & 867 & 129 & 80 & 2238 \\
\hline 2002-2003 & 2.47 & 2.45 & 2.46 & 2.61 & 2.47 & 1113 & 796 & 122 & 65 & 2096 \\
\hline 2003-2004 & 2.56 & 2.55 & 2.66 & 2.86 & 2.57 & 1097 & 754 & 107 & 72 & 2030 \\
\hline 2004-2005 & 2.60 & 2.64 & 2.94 & 3.02 & 2.65 & 1102 & 944 & 109 & 75 & 2230 \\
\hline 2005-2006 & 3.04 & 3.19 & 2.77 & 2.90 & 3.08 & 1223 & 889 & 91 & 69 & 2272 \\
\hline 2006-2007 & 2.69 & 2.66 & 2.84 & 3.06 & 2.70 & 1280 & 830 & 92 & 60 & 2262 \\
\hline 2007-2008 & 2.92 & 2.98 & 2.98 & 3.00 & 2.95 & 1261 & 845 & 97 & 53 & 2256 \\
\hline 2008-2009 & 3.00 & 2.88 & 3.23 & 2.90 & 2.96 & 1317 & 827 & 85 & 66 & 2295 \\
\hline 2009-2010 & 2.90 & - & - & - & 2.90 & 1232 & 0 & 0 & 0 & 1232 \\
\hline Total & 2.68 & 2.63 & 2.75 & 2.72 & 2.67 & 16151 & 11290 & 1432 & 844 & 29717 \\
\hline
\end{tabular}

Note:

In academic year 2005-2006, there was an instructor at UNC-CH who taught 383 and 369 students in the Fall and Spring semester, giving section average grades of 3.61 and 3.76 .

Table A4 reports sample means and standard deviations for the dependent and independent variables that we use in each of our equations. The table reveals a number of interesting characteristics of our data.

First, students who complete a principles course earn an average grade of 2.9 while students who complete post-principles courses earn an average grade of 3.1. However, cross-student grade dispersion as measured by standard deviations is about the same in principles and post-principles courses.

Second, 67 percent complete the principles course during their first year, 21 percent during the sophomore year, 7 percent during their junior year, and 4 percent during their senior year. Not surprisingly, students take intermediate micro and macro later in their careers: 18, 61, 16, and 5 percent of student take intermediate micro during their first through fourth years; 8, 71, 16, and 5 percent take intermediate macro during their first through fourth years.

Third, there is evidence that women select themselves out of post-principles economics courses. While 51 percent of students who complete principles are female, only 39 and 34 percent of those completing intermediate micro and macro are female and only 33 percent of those completing post-principles courses are female. Fourth, only 20 percent of students who take principles are out-of-state residents. We keep track of these students because, as a group, they have higher SAT scores than North Carolina students. 
Table A4

Summary Statistics for Data Used to Estimate the Equations Reported in the Paper

\begin{tabular}{|c|c|c|c|c|c|c|c|c|c|c|}
\hline \multirow{2}{*}{$\begin{array}{l}\text { Variable } \\
\text { Dependent Variable }\end{array}$} & \multicolumn{2}{|c|}{ Grade in Principles } & \multicolumn{2}{|c|}{$\begin{array}{l}\text { Participation in } \\
\text { Intermediate } \\
\text { Micro and } \\
\text { Macro }\end{array}$} & \multicolumn{2}{|c|}{$\begin{array}{l}\text { Grade } \\
\text { in Micro } \\
\text { Economics }\end{array}$} & \multicolumn{2}{|c|}{$\begin{array}{c}\text { Grade } \\
\text { in Macro } \\
\text { Economics }\end{array}$} & \multicolumn{2}{|c|}{$\begin{array}{l}\text { Grade in Other } \\
\text { Economics } \\
\text { Courses }\end{array}$} \\
\hline & 2.894 & $(0.880)$ & $\begin{array}{l}0.341 \\
0.286\end{array}$ & $\begin{array}{l}(0.474) \\
(0.452)\end{array}$ & 3.121 & $(0.837)$ & 3.048 & $(0.792)$ & 3.102 & $(0.871)$ \\
\hline \multicolumn{11}{|l|}{$\begin{array}{l}\text { Principles } \\
\text { Characteristics }\end{array}$} \\
\hline $\begin{array}{l}\text { LT Course } \\
\text { Honors } \\
\text { Grade }^{++} \\
\text {Took as Freshman } \\
\text { Took as Sophomore } \\
\text { Took as Junior } \\
\text { Took as Senior } \\
\text { Took as Other } \\
\text { Student } \\
\text { Characteristics }\end{array}$ & $\begin{array}{l}0.211 \\
0.027\end{array}$ & $\begin{array}{l}(0.408) \\
(0.162)\end{array}$ & $\begin{array}{l}0.186 \\
0.029 \\
0.831 \\
0.663 \\
0.217 \\
0.075 \\
0.040 \\
0.005\end{array}$ & $\begin{array}{l}(0.389) \\
(0.167) \\
(0.937) \\
(0.473) \\
(0.412) \\
(0.264) \\
(0.197) \\
(0.069)\end{array}$ & $\begin{array}{l}0.200 \\
0.032 \\
1.231 \\
0.793 \\
0.162 \\
0.037 \\
0.005 \\
0.003\end{array}$ & $\begin{array}{l}(0.400) \\
(0.175) \\
(0.710) \\
(0.406) \\
(0.369) \\
(0.190) \\
(0.069) \\
(0.052)\end{array}$ & $\begin{array}{l}0.213 \\
0.034 \\
1.279 \\
0.833 \\
0.135 \\
0.025 \\
0.003 \\
0.003\end{array}$ & $\begin{array}{l}(0.410) \\
(0.182) \\
(0.673) \\
(0.373) \\
(0.342) \\
(0.157) \\
(0.058) \\
(0.052)\end{array}$ & $\begin{array}{l}0.182 \\
0.038 \\
1.148 \\
0.750 \\
0.189 \\
0.053 \\
0.006 \\
0.003\end{array}$ & $\begin{array}{l}(0.386) \\
(0.192) \\
(0.738) \\
(0.433) \\
(0.391) \\
(0.225) \\
(0.075) \\
(0.050)\end{array}$ \\
\hline $\begin{array}{l}\text { Female } \\
\text { White } \\
\text { Black } \\
\text { Hispanic } \\
\text { Other } \\
\text { Non-NC resident } \\
\text { Took as Freshman } \\
\text { Took as Sophomore } \\
\text { Took as Junior } \\
\text { Took as Senior } \\
\text { Took as Other } \\
\text { Section } \\
\text { Characteristics }\end{array}$ & $\begin{array}{l}0.507 \\
0.729 \\
0.083 \\
0.055 \\
0.133 \\
0.203 \\
0.665 \\
0.214 \\
0.074 \\
0.043 \\
0.004\end{array}$ & $\begin{array}{l}(0.500) \\
(0.448) \\
(0.276) \\
(0.228) \\
(0.340) \\
(0.402) \\
(0.472) \\
(0.410) \\
(0.261) \\
(0.203) \\
(0.064)\end{array}$ & $\begin{array}{l}0.511 \\
0.743 \\
0.081 \\
0.055 \\
0.121 \\
0.194\end{array}$ & $\begin{array}{l}(0.500) \\
(0.440) \\
(0.273) \\
(0.229) \\
(0.327) \\
(0.296)\end{array}$ & $\begin{array}{l}0.388 \\
0.722 \\
0.082 \\
0.055 \\
0.141 \\
0.237 \\
0.181 \\
0.610 \\
0.159 \\
0.049 \\
0.001\end{array}$ & $\begin{array}{l}(0.487) \\
(0.452) \\
(0.275) \\
(0.228) \\
(0.348) \\
(0.426) \\
(0.385) \\
(0.488) \\
(0.366) \\
(0.215) \\
(0.033)\end{array}$ & $\begin{array}{l}0.343 \\
0.735 \\
0.067 \\
0.062 \\
0.136 \\
0.250 \\
0.079 \\
0.707 \\
0.161 \\
0.053 \\
0.001\end{array}$ & $\begin{array}{l}(0.475) \\
(0.444) \\
(0.250) \\
(0.241) \\
(0.343) \\
(0.433) \\
(0.270) \\
(0.455) \\
(0.367) \\
(0.224) \\
(0.026)\end{array}$ & $\begin{array}{l}0.326 \\
0.730 \\
0.072 \\
0.056 \\
0.142 \\
0.219 \\
0.082 \\
0.452 \\
0.294 \\
0.171 \\
0.001\end{array}$ & $\begin{array}{l}(0.485) \\
(0.445) \\
(0.259) \\
(0.230) \\
(0.349) \\
(0.418) \\
(0.274) \\
(0.498) \\
(0.456) \\
(0.376) \\
(0.038)\end{array}$ \\
\hline $\begin{array}{l}\text { Honors } \\
\text { Size }{ }^{++} \\
\text {Day: } \mathrm{TTH}=1 \\
\text { Hour of day }{ }^{++} \\
\text {Instructor } \\
\text { Characteristics }\end{array}$ & $\begin{array}{r}0.027 \\
47.180 \\
0.370 \\
2.789\end{array}$ & $\begin{array}{r}(0.162) \\
(98.724) \\
(0.483) \\
(1.761)\end{array}$ & & & $\begin{array}{r}0.012 \\
-3.957 \\
0.383 \\
2.797\end{array}$ & $\begin{array}{r}(0.110) \\
(20.795) \\
(0.486) \\
(1.819)\end{array}$ & $\begin{array}{r}0.023 \\
11.549 \\
0.389 \\
2.842\end{array}$ & $\begin{array}{r}(0.151) \\
(42.481) \\
(0.488) \\
(1.848)\end{array}$ & $\begin{array}{l}0.009 \\
3.158 \\
0.438 \\
2.744\end{array}$ & $\begin{array}{l}(0.097) \\
(39.04) \\
(0.496) \\
(1.804)\end{array}$ \\
\hline $\begin{array}{l}\text { Teaching Assistant } \\
\text { Female } \\
\text { Semester } \\
\text { Characteristics }\end{array}$ & & & & & $\begin{array}{l}0.037 \\
0.226\end{array}$ & $\begin{array}{l}0.189) \\
(0.418)\end{array}$ & $\begin{array}{l}0.036 \\
0.234\end{array}$ & $\begin{array}{l}(0.187) \\
(0.423)\end{array}$ & 0.471 & $(0.500)$ \\
\hline $\begin{array}{l}\text { Year }^{++} \\
\text {Semester: Fall } \\
\text { Semester: Spring } \\
\text { Semester: Summer }\end{array}$ & $\begin{array}{l}1.338 \\
0.671 \\
0.329\end{array}$ & $\begin{array}{l}(1.050) \\
(0.482) \\
(0.470)\end{array}$ & & & $\begin{array}{l}1.611 \\
0.594 \\
0.314 \\
0.092 \\
\end{array}$ & $\begin{array}{l}(0.906) \\
(0.497) \\
(0.464) \\
(0.289)\end{array}$ & $\begin{array}{l}1.730 \\
0.620 \\
0.300 \\
0.080 \\
\end{array}$ & $\begin{array}{l}(0.791) \\
(0.489) \\
(0.458) \\
(0.271)\end{array}$ & $\begin{array}{l}1.818 \\
0.620 \\
0.305 \\
0.075 \\
\end{array}$ & $\begin{array}{l}(0.827) \\
(0.500) \\
(0.460) \\
(0.263)\end{array}$ \\
\hline $\begin{array}{l}\text { Dependent Variable } \\
\text { Units } \\
\text { Sample Size } \\
\text { Data set }\end{array}$ & & & & $\begin{array}{l}\text { lent } \\
67 \\
3\end{array}$ & & $\begin{array}{l}\text { ade } \\
71 \\
1\end{array}$ & & $\begin{array}{l}\text { ade } \\
55 \\
\end{array}$ & $\mathrm{Gr}$ & \\
\hline
\end{tabular}

Notes:

+ Students who completed principles during fall or spring semesters but completed post-principles courses in summer school are retained in the data used to estimate our equations.

++ Norms are chosen for course grades (2.0), class size (300 in principles and 50 in other courses), hour of day (8:00 AM), and year $(0=2006, . ., 3=2009)$. 


\section{APPENDIX B: CONTENT OF THE LITERACY TARGETED PRINCIPLES COURSE}

This appendix describes the content of the Literacy Targeted (LT) Principles Course taught by Michael Salemi and makes the affirmative case that the course targeted economic literacy. The detailed description may interest economic educators who are considering revision in their principles of economics courses.

The syllabus of the LT course explained that the goal of the course was to help students become literate in basic economic ideas. It included the following course goal.

The purpose of this course is to change the way you look at the world. The course focuses on core economic concepts and provides opportunities to practice using them in contexts like you will encounter throughout your lives. Your success in this course will be determined later in your life when you understand what economics has to say about taxes, environmental rules, trade agreements, free markets, unintended consequences of well-intended policies, and many other issues. The goal of the course is to help you think like an economist in ways that will help you make better decisions. It is up to you to decide how valuable the economist's perspective is.

Table B1 provides an overview of the LT course syllabus. The LT course assigned about one chapter per week from the Frank and Bernanke text. Outside readings supported the course's focus on key economic concepts. Students read the first four chapters of the Wealth of Nations, Radford's "Economics Organization of a P.O.W. Camp, and the "Introduction to Monetary Policy" published by the Federal Reserve Bank of San Francisco.

The LT course devoted more class time to the fundamental economic concepts than traditional courses do. For example, it devoted 300 minutes of lecture to the concepts of opportunity cost, the benefit-cost principle and comparative advantage and 375 minutes of lecture and 100 minutes of recitation to demand and supply.

The LT course did not cover cost concepts in the traditional way. While the LT course covered the marginal cost schedule, it did not cover the average total cost, average variable cost and average fixed cost schedules. The LT course did explain the connection between the marginal cost schedule and the cost-benefit principle, the shape of the marginal cost schedule, and how both price taking and price setting decision makers use the information in the marginal cost schedule to make output decisions. It also required students to be able to compute marginal cost in a variety of settings and scenarios so that they would understand how to use "marginal cost” in making their own decisions.

The LT course did not cover market structure in the traditional way. It did cover purely competitive markets, horizontal marginal revenue schedules, and the result that competitive markets produce Pareto optimal allocations. It also covered price setting behavior, sources of market power, downward sloping marginal revenue schedules, and the result that price setters choose allocations that are not Pareto optimal. The course did not cover monopoly, oligopoly, and monopolistic competition separately and did not ask students to differentiate among these non-competitive industry models. 
The LT course did not cover game theory but did cover externalities, the Coase Theorem, and markets for pollution rights. We acknowledge that instructors might be committed to a literacy targeted course but believe that students would obtain greater long-term benefits from learning about game theory than from learning about externalities. Hansen, Salemi and Siegfried argue that reasonable people can differ about which topics best promote student literacy provided that the number of topics is sufficiently small to permit students to master the included topics.

The LT course covered macroeconomics in a way that differs greatly from traditional courses. For example, it did not cover the one-sector Keynesian macroeconomic model in which interest rates, prices, and wages are constant, the Keynesian cross, or spending multipliers.

The LT course devoted substantial effort to helping students master the concept of the real rate of interest. Kennedy (2000) argues that the real rate of interest is an important and under-emphasized principles concept. Taylor (2000) suggests that principles instructors use a version of the IS schedule to model the relationship between aggregate output and the real interest rate and that they treat the nominal interest rate as the monetary policy instrument. A Federal Reserve commitment to low and steady inflation pins down the expected inflation rate and implies that nominal and real rates move together so that Taylor's model is easy for principles students to understand. The LT course devoted 150 minutes to the real rate of interest, 75 minutes to presentation of a one-diagram model that explains fluctuations in output, and 75 minutes to a lecture that uses the model to explain the conduct of monetary policy.

The LT course included assignments that helped students transfer their economic understanding to contexts and tasks they will encounter throughout their lives. The course required students to make five postings to an economics journal. For each posting, students were required to find a news article and write a 100-200 word essay in which they used the concept-of-the-day to interpret the reading. In their first posting students used "opportunity cost" and the "benefit cost principle" to interpret an article about scarcity. In the second, students used demand and supply to interpret an article about allocation. For the third, students found an article that explained a comparative advantage of the United States and explained how exploiting that advantage would lead to the creation of jobs and wealth. For the fourth posting, students found an article about a macro policy issue and explained why the policy issue was important. For the fifth posting, students found an article that described the current state of monetary policy and explained why the Fed was more likely to raise or lower interest rates.

The LT course included hands-on assignments that helped students gain a deeper understanding and working knowledge of key concepts. Students participated in a second-price auction conducted in class to deepen their understanding of "reservation prices." They participated in a double-oral auction in their recitations and then had an opportunity to view the aggregated results from all the auctions. The auction exercise and its debriefing in lecture helped students understand how markets work and assess the accuracy of the demand and supply model in predicting equilibrium price. Students discussed chapters one through four of the Wealth of Nations and "The Economics of a POW Camp" in recitation using the inquiry-based discussion technology explained in Salemi and Hansen (2005). Discussing the Wealth of Nations helped students better understand the connection between specialization, wealth, and economic trade. Discussing “The Economics of a POW Camp” helped students better understand that large 
economic benefits derive from trade and that societies create money endogenously to make trade easier to accomplish.

The course also required students to interpret economic data. Hansen (2001) argues that one of the proficiencies that students who study economics should gain is the ability to bring data to bear on economic arguments. While Hansen is primarily concerned with proficiencies achieved by undergraduate majors, it is our view that interpreting data available at online sources such as FRED ${ }^{\circledR}$ is a skill that will serve students well throughout their lives. Students used data to compute the long run growth rate of the US economy, to identify periods of high and low inflation, to identify interesting trends in the GDP shares of consumption, investment, government spending and net exports over the post-WWII period, and to explore the bivariate relationship between money growth and inflation.

The course employed several instructional strategies designed to promote student engagement with course concepts. The instructor used clicker activities such as peer instruction and small stakes quizzes to provide students with opportunities to check their thinking. The instructor also conducted exercises designed to show the relevance of economics to everyday life. On the first day of class, the instructor asked each student to write down the "opportunity cost” of attending a party. Later in the course, the instructor asked students whether (and why) they believed that the distribution system for student tickets to UNC basketball games was efficient in the economic sense of the term. The instructor frequently began lectures with a current news article related to the day's objectives. 
Table B1

Topic Coverage of the Literacy Targeted Principles of Economics Course

\begin{tabular}{|c|c|c|c|c|}
\hline Topic & $\begin{array}{l}\text { Lecture } \\
\text { Minutes }\end{array}$ & Percent & Reading Assignments ${ }^{1}$ & Recitation Activities $^{2}$ \\
\hline $\begin{array}{l}\text { Scarcity, Choice and } \\
\text { Opportunity Cost }\end{array}$ & 150 & 7.4 & FB 1 & $\begin{array}{l}\text { Discuss Scarcity Questions } \\
\text { Debrief First Journal } \\
\text { Assignment }\end{array}$ \\
\hline Comparative Advantage & 150 & 7.4 & $\begin{array}{l}\text { FB } 2 \\
\text { Chapters 1-4, Wealth of Nations }\end{array}$ & Discuss Wealth of Nations \\
\hline Demand and Supply & 375 & 18.5 & FB 3, 5, 6 & $\begin{array}{l}\text { Conduct Trading Simulation } \\
\text { Discuss Demand and Supply } \\
\text { Problems } \\
\text { Debrief Second Journal } \\
\text { Assignment }\end{array}$ \\
\hline Elasticity of Demand & 75 & 3.7 & FB 4 & \\
\hline $\begin{array}{l}\text { Price Taking and Economic } \\
\text { Efficiency }\end{array}$ & 150 & 7.4 & $\begin{array}{l}\text { FB } 7 \\
\text { "The Economic Organization of a } \\
\text { P.O.W. Camp” }\end{array}$ & $\begin{array}{l}\text { Discuss “Economic } \\
\text { Organization” }\end{array}$ \\
\hline Economic Profit and Rent & 75 & 3.7 & FB 8 & \\
\hline International Trade & 75 & 3.7 & FB 28 & $\begin{array}{l}\text { Debrief Third Journal } \\
\text { Assignment }\end{array}$ \\
\hline $\begin{array}{l}\text { Market Power and Price } \\
\text { Setting }\end{array}$ & 75 & 3.7 & FB 9 & $\begin{array}{l}\text { Discuss Efficiency and Market } \\
\text { Power Exercises }\end{array}$ \\
\hline $\begin{array}{l}\text { Externalities and Property } \\
\text { Rights }\end{array}$ & 150 & 7.4 & FB 11 & \\
\hline $\begin{array}{l}\text { Macroeconomic Concepts and } \\
\text { Data } \\
\text { (Output, Prices and Wages) }\end{array}$ & 225 & 11.1 & FB $16,17,18$ & $\begin{array}{l}\text { Complete Macroeconomic } \\
\text { Data Exercise } \\
\text { Debrief Fourth Journal } \\
\text { Assignment }\end{array}$ \\
\hline $\begin{array}{l}\text { Economic Growth and } \\
\text { Productivity }\end{array}$ & 75 & 3.7 & FB 19 & \\
\hline The Real Rate of Interest & 150 & 7.4 & FB 20 & $\begin{array}{l}\text { Discuss Real Rate of Interest } \\
\text { Exercises }\end{array}$ \\
\hline $\begin{array}{l}\text { Modeling Macroeconomic } \\
\text { Equilibrium }\end{array}$ & 75 & 3.7 & Instructor Notes & \\
\hline Macroeconomic Policy & 150 & 7.4 & $\begin{array}{l}\text { U.S. Monetary Policy: An } \\
\text { Introduction }\end{array}$ & $\begin{array}{l}\text { Discuss Monetary Policy } \\
\text { Exercises } \\
\text { Debrief Fifth Journal } \\
\text { Assignment }\end{array}$ \\
\hline Course Review & 75 & 3.7 & & \\
\hline Totals & 2025 & 100 & $\begin{array}{l}16 \text { Chapters, Three Other } \\
\text { Readings }\end{array}$ & \\
\hline
\end{tabular}

Notes

1. FB refers to Chapters in the Primis Edition of Frank and Bernanke described in the text and listed in the reference section. 2. Recitation activities are listed by the topics they reinforced rather than by week. Some recitations were devoted to helping students prepare for and then debrief examinations. 


\section{NOTES}

${ }^{1}$ Our coefficient estimate implies that raising class size by 100 students lowers the average grade earned by 0.10 grade points.

${ }^{2}$ North Carolina mandates that at least 85 percent of each first year class comprise North Carolina residents.

${ }^{3}$ We were not able to determine what sort of student mastery translates to success in intermediate economic theory courses in part because of great variation in intermediate theory instructors and syllabi.

${ }^{4}$ In order to conserve journal space, we do not report these regression results in the paper. However, the results are available from the corresponding author on request.

${ }^{5}$ In order to conserve journal space, we do not report regression results based on different sub samples in the paper. However, those results are available from the corresponding author on request.

${ }^{6}$ In order to conserve journal space, we do not report the Heckman regression results in the paper. However, those results are available from the corresponding author on request. 